\title{
Iron absorption from typical West African meals containing contaminating Fe
}

\author{
BY PILAR GALAN ${ }^{1}$, FRANÇOISE CHEROUVRIER ${ }^{1}$, ISIDORE ZOHOUN ${ }^{2}$, \\ THÉOPHILE ZOHOUN ${ }^{3}$, MICHEL CHAULIAC ${ }^{4}$ AND SERGE HERCBERG ${ }^{1 *}$ \\ ${ }^{1}$ Centre de Recherche sur les Anémies Nutritionnelles, Institut Scientifique et Technique de \\ l'Alimentation, CNAM 2 rue Conté, F-75003 Paris, France \\ ${ }^{2} \mathrm{CNHU}$, Cotonou, Bénin, W. Africa \\ ${ }^{3}$ Faculté de Médecine, Cotonou, Benin, W. Africa \\ ${ }^{4}$ Centre International de l'Enfance, Paris, France
}

(Received 9 August 1989 - Accepted 22 March 1990)

\begin{abstract}
Iron absorption from three typical West African meals was measured in fourteen subjects using the extrinsic-tag technique with ${ }^{59} \mathrm{Fe}$ and ${ }^{55} \mathrm{Fe}$. All meals consisted of maize as the staple food. Meals were prepared in Benin under realistic conditions from locally grown foods. Of the non-haem-Fe in the meals $39-73 \%$ did not exchange with the added inorganic radio-Fe tracer, depending on the degree of $\mathrm{Fe}$ contamination of meals. Non-haem-Fe absorption was low in each maize meal, but was even lower for those eaten with a vegetable sauce than for those eaten with a fish sauce. When haem-Fe absorption was included, 70.0-160 $\mu \mathrm{g}$ Fe was absorbed. Expressed on an energy basis, the bioavailable nutrient density was 3.2-7.0 $\mu \mathrm{g} / 100 \mathrm{~kJ}(13.4-29.5 \mu \mathrm{g} / 100 \mathrm{kcal})$. These findings suggest that total Fe available in the typical diets of West African countries does not meet the physiological requirements of large proportions of the population.
\end{abstract}

Food iron absorption: Contamination iron: African meals

Food in Africa, as in many developing countries, is often contaminated by iron from soil residues in cereals and vegetables, or by dust that has settled on the surface during air drying (Hercberg et al. 1987a). The Fe content of African meals is therefore often much higher than the content of native food $\mathrm{Fe}$, as calculated from food composition tables. The bioavailability of this contaminating Fe is poorly documented, but it seems to be quite low in view of the high prevalence of Fe deficiency in African countries.

The absorption of non-haem-Fe may be determined by measuring the proportion of radio-Fe absorbed and multiplying by the proportion of non-haem-Fe present in the meal (Cook et al. 1972). The extrinsic tag method has been demonstrated over the years to be a reliable technique for measuring the absorption of non-haem-Fe in a meal (Hallberg, 1980). However, it implies a complete isotopic exchange between an inorganic radio- $\mathrm{Fe}$ tracer added to the meal and the native non-haem-Fe compounds in the foods, which may not necessarily be the case for contaminating Fe. Hallberg \& Bjorn-Rasmussen (1981) described an in vitro method for assessing the extent of isotopic exchange between native non-haem-Fe and an added inorganic radio-Fe tracer. The combination of the measurement of exchangeability of non-haem-Fe and the use of the extrinsic-tag method make it possible to evaluate the absorption of non-haem-Fe from meals contaminated with Fe. Moreover several findings (Hallberg et al. 1979) have shown that the amount of haem$\mathrm{Fe}$ absorbed may be estimated using a value of $25 \%$. Thus, in developing countries, total

* For reprints. 
Fe absorbed (non-haem- and haem-Fe) may be evaluated from typical meals prepared in the home from locally grown foods. Paradoxically, little information exists on $\mathrm{Fe}$ absorption from meals contaminated with Fe and no information is available concerning African meals.

The present study was conducted in order to measure food Fe absorption from different kinds of typical West African meals under realistic field conditions in populations where meals may be contaminated with Fe from the soil, dust or water, and where Fe deficiency has been demonstrated to be highly prevalent.

\section{MATERIALS AND METHODS}

\section{Materials}

The study was conducted in fourteen Beninese men aged 24.5 (SE 0.53; range 23-28) years. All subjects were medical students or were employed in the hospital at Cotonou. They all considered themselves to be healthy. All volunteers were informed in detail about the purpose of the study and the nature of the investigation, and gave written informed consent before their participation in the study; procedures followed were in accord with standards of the ethical committee of the CNAM.

\section{Fe absorption tests}

Fe absorption tests were performed in each subject by a double radioisotope technique. After obtaining blood samples for measurement of background radioactivity and $\mathrm{Fe}$ status, meals $\mathrm{A}$ and $\mathrm{B}$, labelled respectively with $3 \mu \mathrm{Ci}{ }^{55} \mathrm{FeCl}_{3}$ or $1.5 \mu \mathrm{Ci}{ }^{59} \mathrm{FeCl}_{3}$ were administered on consecutive mornings (day 1 and day 2) after an overnight fast. After 2 weeks (day 15), a blood sample was withdrawn to determine the absorption of the two radio-Fe isotopes, and the third meal (meal C) labelled with $3 \mu \mathrm{Ci}^{55} \mathrm{FeCl}_{3}$ was served. The following day (day 16), an oral reference dose of inorganic Fe containing $3 \mathrm{mg}$ elemental $\mathrm{Fe}$ in the form of ferrous ascorbate labelled with ${ }^{59} \mathrm{Fe}$ was served in a cold beverage. After 2 weeks, a second blood sample was drawn to measure the absorption from meal $\mathrm{C}$ and the reference dose. This was calculated from the increase in blood radioactivity between days 16 and 29 . Assays for ${ }^{55} \mathrm{Fe}$ and ${ }^{59} \mathrm{Fe}$ were performed on duplicate $10 \mathrm{ml}$ blood samples using a modification of the method of Eakins \& Brown (1966). Absorption was determined on the basis of blood volume estimated from height and weight. Erythrocyte incorporation of absorbed radioactivity was assumed to be $80 \% 2$ weeks after ingestion of radio-Fe. Determination of ${ }^{55} \mathrm{Fe}$ and ${ }^{59} \mathrm{Fe}$ was carried out using liquid scintillation counting (Delta 300, 6890 Liquid Scintillation System, Searle Analytic Inc.).

\section{Experimental design}

The study was performed in a restaurant kitchen in Cotonou, Benin, under close supervision of the organizing team. Foods were bought in the Cotonou local market and standard procedures were used for cooking. All food items were carefully weighed using a Terraillon balance. All test meals were administered between 09.00 and 11.00 hours after an overnight fast, and water alone was allowed for $3 \mathrm{~h}$.

\section{Type of meals}

Meals were typical diets consumed by the majority of people living in South Benin and in other countries of West Africa.

Meal $A$ : maize paste ('Wo') with vegetable sauce ( $\mathrm{g} /$ subject). Maize flour (110) was made up into a paste with $340 \mathrm{ml}$ water. Vegetable sauce $(210)$ consisted of green leaves 98 , 
tomatoes 49 , onions 10 , fried fish 20 , palm oil 9 , red peppers 2 , concentrated tomato sauce $3 \cdot 5$, salt, and black pepper.

Meal B: fermented maize paste ('Akassa') with fish sauce and leaf sauce ('Crin-Crin') (g/subject). Maize flour ( $160 \mathrm{~g}$ ) was made up into a paste with $190 \mathrm{ml}$ water. The paste was left to ferment for $24 \mathrm{~h}$. Fish sauce (120) consisted of fresh fish 69 , tomatoes 41 , onions 11 , concentrated tomato sauce 4 , red peppers 2 , peanut oil 5 , black pepper, and salt. Crin-Crin sauce (40) was composed of green leaves 14 with dried fish, salt and water.

Meal $C$ : maize paste (Wo) with fish sauce and leaf sauce (Crin-crin) (g/subject). Maize flour (120) was made up into a paste with $230 \mathrm{ml}$ water. Fish sauce (120) consisted of fresh fish 26 , tomatoes 57 , onions 11 , concentrated tomato sauce 5 , peanut oil 5 , red peppers 3 , black pepper, and salt. Crin-Crin sauce (40) was identical to that in meal B.

\section{Chemical composition of meals}

All meals were duplicated and mixed for analysis of chemical composition. Proteins, fat and carbohydrates were measured according to the Association of Analytical Chemists (1975) methods, and total Fe and non-haem-Fe according to Schriker \& Miller (1982). The proportion of non-haem-Fe that exchanged with an added inorganic tracer was determined by the method described by Hallberg \& Bjorn-Rasmussen (1981). This is an in vitro technique in which foods are digested with pepsin and trypsin in the presence of radio-Fe. The extent of isotopic exchange between the tracer and the non-haem-Fe in the food was calculated from the specific activity in the food and in an extract of bathophenantroline in isoamyl alcohol obtained after digesting the foods.

\section{Measurement of Fe status}

The haemoglobin concentration was measured using a Coulter Counter model S, and erythrocyte protoporphyrin was estimated using an automatic model 5 hematofluorometer (Aviv Biomedical). Serum Fe was measured by the colorimetric method using ferrozine (Giovanello et al. 1968). A nephelometry assay (laser nephelometer Behring) was used to measure transferrin, and total Fe-binding capacity was calculated (Conrad et al. 1978). Serum ferritin was determined using an enzyme-linked immunosorbent assay (Voller \& De Savigny, 1981).

\section{Treatment of results}

Because of the highly skewed distribution of Fe absorption values when expressed as a percentage of the administered dose, individual values were converted to logarithms for statistical analysis and the results were reconverted to antilogarithms to recover the original units (Cook et al. 1969). All values for $\mathrm{Fe}$ absorption and meal ratios are reported as geometric means.

\section{RESULTS}

Table 1 shows the nutrient content of the three meals studied for $\mathrm{Fe}$ absorption. The $\mathrm{Fe}$ content (mg) was 6.55 for meal A, 6.33 for meal B and 4.70 for meal C, corresponding to an Fe density of $0.286,0.208$ and $0.239 \mathrm{mg} / \mathrm{kJ}(1.20,0.87$ and $1.00 \mathrm{mg} / 100 \mathrm{kcal})$. Haemand non-haem-Fe contents of meals and results of studies on the exchangeability of nonhaem-Fe in test meals are shown in Table 1. Non-haem-Fe represented (\% total $\mathrm{Fe}$ ) $98 \cdot 3$ for meal A, 94.1 for meal B and 97.2 for meal C. The three meals contained some Fe that did not exchange with the added inorganic tracer. The exchangeability of non-haem-Fe varied from 39 to $73 \%$ according to the meal.

Anthropometric values, Fe status measurements and Fe absorption tests of the three meals for the fourteen volunteers are listed in Table 2. Non-haem-Fe absorption was low 
Table 1. Nutritional composition, iron content and exchangeable non-haem-Fe for the three typical West African meals

\begin{tabular}{|c|c|c|c|c|c|c|c|c|c|c|}
\hline \multirow{3}{*}{ Meal } & \multicolumn{2}{|c|}{ Energy } & \multirow[b]{2}{*}{$\begin{array}{l}\text { Protein } \\
\text { (g) }\end{array}$} & \multirow[b]{2}{*}{$\begin{array}{l}\text { Lipids } \\
\text { (g) }\end{array}$} & \multirow[b]{2}{*}{$\begin{array}{l}\text { Carbohydrates } \\
\text { (mg) }\end{array}$} & \multirow{2}{*}{$\begin{array}{l}\text { Total } \\
\text { (mg) }\end{array}$} & \multicolumn{2}{|l|}{$\mathrm{Fe}$} & \multicolumn{2}{|c|}{$\begin{array}{l}\text { Exchangeable } \\
\text { non-haem-Fe }\end{array}$} \\
\hline & $\mathrm{kJ}$ & $(\mathrm{kcal})$ & & & & & $\begin{array}{c}\text { Non-haem } \\
\text { (mg) }\end{array}$ & $\begin{array}{l}\text { Haem } \\
(\mathrm{mg})\end{array}$ & $\%$ & $\mathrm{mg}$ \\
\hline & $-\ldots$ & - _ . & $-\ldots$ & $-\ldots$ & $\cdots-\ldots$ & & $-\ldots-$ & & -- & \\
\hline A & 2280 & 545 & $22 \cdot 5$ & 13.0 & $84 \cdot 3$ & 6.55 & 6.44 & 0.11 & $58 \cdot 5$ & 3.74 \\
\hline B & 3037 & 726 & $23 \cdot 2$ & $23 \cdot 2$ & $102 \cdot 6$ & $6 \cdot 33$ & 5.98 & $0 \cdot 35$ & $38 \cdot 9$ & $2 \cdot 33$ \\
\hline $\mathrm{C}$ & 1966 & 470 & $20 \cdot 0$ & $9 \cdot 6$ & $75 \cdot 7$ & $4 \cdot 70$ & $4 \cdot 57$ & $0 \cdot 13$ & $72 \cdot 8$ & $3 \cdot 32$ \\
\hline
\end{tabular}

Meal A, maize paste (Wo) with vegetable sauce; meal B, fermented maize paste (Akassa) with fish sauce and leaf sauce (Crin-Crin); meal C, maize paste (Wo) with fish sauce and leaf sauce (Crin-Crin); for details, see pp. $542 \cdot 543$.

Table 2. Characteristics of volunteers and non-haem-iron absorption for the three typical West African meals

\begin{tabular}{|c|c|c|c|c|c|c|c|c|c|c|c|c|}
\hline $\begin{array}{l}\text { Sub- } \\
\text { ject } \\
\text { no. }\end{array}$ & $\begin{array}{c}\text { Age } \\
\text { (years) }\end{array}$ & $\begin{array}{l}\text { Height } \\
(\mathrm{cm})\end{array}$ & $\begin{array}{l}\mathrm{Wt} \\
(\mathrm{kg})\end{array}$ & $\begin{array}{c}\mathrm{Hb} \\
(\mathrm{g} / \mathrm{l})\end{array}$ & $\begin{array}{c}\text { Serum } \\
\mathrm{Fe} \\
(\mu \mathrm{mol} / \mathrm{l})\end{array}$ & $\begin{array}{l}\text { Trans- } \\
\text { ferrin } \\
\text { satur- } \\
\text { ation } \\
(\%)\end{array}$ & $\begin{array}{l}\text { Eryth- } \\
\text { rocyte } \\
\text { proto- } \\
\text { porph- } \\
\text { yrin } \\
(\mu \mathrm{g} / \mathrm{g} \mathrm{Hb})\end{array}$ & $\begin{array}{c}\text { Serum } \\
\text { ferr- } \\
\text { itin } \\
(\mu \mathrm{g} / \mathrm{l})\end{array}$ & $\begin{array}{l}\text { Non-h: } \\
\text { absorp } \\
\text { Meal } \\
\text { A }\end{array}$ & $\begin{array}{l}\text { dem-Fe } \\
\text { tion } \% \\
\text { Meal } \\
\text { B }\end{array}$ & $\begin{array}{c}\text { Meal } \\
\mathrm{C}\end{array}$ & $\begin{array}{l}\text { Refer- } \\
\text { ence } \\
\text { dose* }\end{array}$ \\
\hline 1 & 26 & 175 & 55 & 164 & 14.5 & 0.21 & 1.9 & 154 & 0.5 & $1 \cdot 7$ & $0 \cdot 2$ & $2 \cdot 3$ \\
\hline 2 & 23 & 165 & 55 & 158 & 18.7 & 0.24 & $2 \cdot 9$ & 55 & $1 \cdot 3$ & $2 \cdot 3$ & $8 \cdot 8$ & 70.5 \\
\hline 3 & 23 & 167 & 78 & 151 & 16.7 & $0 \cdot 26$ & $1 \cdot 8$ & 35 & 1.0 & $3 \cdot 8$ & $3 \cdot 1$ & 55.0 \\
\hline 4 & 25 & 167 & 61 & 158 & 15.0 & 0.21 & $2 \cdot 3$ & 49 & 0.4 & 1.9 & $10 \cdot 2$ & $65 \cdot 1$ \\
\hline 5 & 23 & 174 & 55 & 164 & $18 \cdot 3$ & 0.22 & 1.9 & 53 & $2 \cdot 0$ & $4 \cdot 4$ & 0.6 & $8 \cdot 3$ \\
\hline 6 & 23 & 169 & 46 & 142 & $19 \cdot 2$ & 0.31 & 1.7 & 85 & $1 \cdot 0$ & 3.8 & 0.5 & 9.9 \\
\hline 7 & 23 & 157 & 51 & 165 & $30 \cdot 2$ & 0.51 & $2 \cdot 2$ & 112 & $0 \cdot 3$ & 1.5 & $7 \cdot 3$ & $33 \cdot 5$ \\
\hline 8 & 28 & 174 & 72 & 146 & $20 \cdot 2$ & $0 \cdot 31$ & 2.0 & 42 & $2 \cdot 2$ & $7 \cdot 1$ & $11 \cdot 8$ & 15.9 \\
\hline 9 & 25 & 175 & 69 & 148 & $10 \cdot 0$ & 0.15 & $2 \cdot 0$ & 73 & 10 & 3.7 & 1.7 & $21 \cdot 2$ \\
\hline 10 & 24 & 176 & 60 & 150 & $19 \cdot 6$ & 0.29 & $2 \cdot 5$ & 68 & 0.8 & 0.8 & $5 \cdot 2$ & $27 \cdot 0$ \\
\hline 11 & 24 & 164 & 43 & 169 & $23 \cdot 3$ & 0.28 & $2 \cdot 1$ & 93 & 29 & $6 \cdot 3$ & 6.0 & $38 \cdot 1$ \\
\hline 12 & 23 & 172 & 54 & 150 & $14 \cdot 4$ & 0.18 & $2 \cdot 4$ & 50 & $5 \cdot 8$ & 8.0 & $9 \cdot 4$ & $51 \cdot 7$ \\
\hline 13 & 26 & 178 & 71 & 138 & 15.9 & $0 \cdot 24$ & $2 \cdot 5$ & 29 & $2 \cdot 7$ & 5.9 & 6.1 & $52 \cdot 6$ \\
\hline 14 & 27 & 177 & 70 & 145 & 23.6 & $0 \cdot 30$ & $2 \cdot 4$ & 59 & $1 \cdot 4$ & $1 \cdot 7$ & $2 \cdot 2$ & $14 \cdot 1$ \\
\hline Mean & 25 & 171 & 60 & 153 & $18 \cdot 5$ & 0.27 & $2 \cdot 2$ & $57 \dagger$ & $1 \cdot 2 \dagger$ & $3 \cdot 1 \dagger$ & $3.2 \dagger$ & $24 \cdot 0 \dagger$ \\
\hline SEM & 0.53 & $1 \cdot 60$ & 2.67 & $2 \cdot 4$ & 1.28 & 0.02 & 0.08 & - & - & $\cdots$ & $\ldots$ & -- \\
\hline
\end{tabular}

Hb, haemoglobin.

* Reference dose: $3 \mathrm{mg}$ elemental $\mathrm{Fe}$ in the form of ferrous ascorbate labelled with ${ }^{59} \mathrm{Fe}$ served in a cold beverage.

$\uparrow$ Geometric mean.

in each meal, particularly for the maize meal eaten with a vegetable sauce (meal A). The geometric mean percentage of $\mathrm{Fe}$ absorption of exchangeable non-haem-Fe varied from $1 \cdot 2$ to $3.2 \%$ according to the meal. This corresponded to amounts of absorbed Fe $(\mu \mathrm{g})$ of 45 for meal A, 72 for meal B and 106 for meal C. The absorption of haem-Fe was not measured. An estimate of the amount of haem-Fe absorbed was made using an absorption value of $25 \%$ based on previous work (Hallberg et al. 1979). When including haem-Fe absorption, $73.0,160$ and $139 \mu \mathrm{g} F \mathrm{Fe}$ were absorbed. This corresponded to a global coefficient of absorption ( $\%$ ) of $1 \cdot 1,2.5$ and 3.0 according to the total Fe content of meals, or, respectively, $1.9,60$ and 4.0 if results were related to exchangeable Fe content. 
Expressed per unit of energy, the bioavailable nutrient density for meals $A, B$ and $C$ corresponded to $3.20,5.26$ and $7.05 \mu \mathrm{g} / \mathrm{kJ}(13.4,22.0$ and $29.5 \mu \mathrm{g} / 100 \mathrm{kcal})$ respectively.

\section{DISCUSSION}

Although Fe deficiency is particularly prevalent in African countries, few studies on dietary Fe absorption have been performed on typical African diets, and no study on West African meals is available. This is unfortunate since, in many African countries, Fe deficiency is widespread despite a high dietary intake, which may be related to a high degree of $\mathrm{Fe}$ contamination. From the present study, it clearly appears that $\mathrm{Fe}$ contamination may be relatively important in common Beninese foods. The amount of Fe contamination is much higher than the $\mathrm{Fe}$ content of native food. These findings are consistent with our previous findings concerning $\mathrm{Fe}$ content in Senegalese foods (Guiro \& Hercberg, 1988). Contaminating $\mathrm{Fe}$ exchanged only partially with the organic radio-Fe tracer. Thus, using the extrinsic tag method, it is not possible to calculate the amount of Fe absorbed from the percentage of radio- $\mathrm{Fe}$ using the total $\mathrm{Fe}-$ haem-Fe content of foods. Contaminating $\mathrm{Fe}$ does not completely enter the common non-haem-Fe pool from which $\mathrm{Fe}$ is thought to be absorbed. Some of this Fe exchanges with the radiotracer. The part of non-haem-Fe that does not exchange with the radiotracer is unavailable for absorption.

Our results indicate that $\mathrm{Fe}$ absorption is, in general, very low (between $1 \cdot 1$ and $3.0 \%$ ) in typical West African diets. These coefficients are higher when results are not related to total $\mathrm{Fe}$ content of meals (native and contaminating $\mathrm{Fe}$ ) but are related only to exchangeable Fe. However, in absolute terms, the amount of absorbed Fe is very low. From a public health viewpoint, the most valid concept for predicting the coverage of $\mathrm{Fe}$ requirements in populations is that of bioavailable nutrient density (Fe absorbed/unit energy intake).

We observed that variations in Fe absorption from the different meals were due in large part to variations in the quantities of animal tissue proteins (particularly fish) contained in the meals. In our study, maize meal with vegetable sauce had a lower Fe absorption than the same maize meal with fish sauce. Fermentation of maize seemed to increase $\mathrm{Fe}$ absorption.

It is probable that the amounts of absorbed $\mathrm{Fe}$ are higher in Fe-deficient subjects. Previous findings (Hallberg, 1980; Magnusson et al. 1981; Hallberg et al. 1983) have demonstrated that absorption of the reference dose in subjects with depleted Fe stores is about $40 \%$. If we express absorption from the tested meals as the value corresponding to a reference absorption of $40 \%$, the absorption coefficient will be extrapolated to $1.9 \%$ for maize meal with vegetable sauce and to 4.9 and $6.0 \%$ for maize meal with fish sauce.

Non-haem-Fe absorption thus appears to be very low in typical African meals. These results are consistent with values observed for Latin-American diets, in which non-haem$\mathrm{Fe}$ absorption varied between 1 and $4 \%$ (Cook et al. 1971). On the whole, total $\mathrm{Fe}$ absorption was higher in Latin-American diets than in African diets, due to haem-Fe intakes related to a higher intake of meat and fish.

Our results enable us to understand why a large proportion of the population, which consumes diets deficient in absorbable $\mathrm{Fe}$, develops varying degrees of $\mathrm{Fe}$ deficiency, especially in those groups with high physiological Fe requirements. Recent epidemiological studies which we performed in Benin (Hercberg et al. 1986, 1987 a, b, 1988) in a population consuming this type of diet show that Fe deficiency (defined by a reliable combination of several independent $\mathrm{Fe}$ indicators) was present in $31 \%$ of menstruating women, $73 \%$ of pregnant women, $25 \%$ of adolescents and $13 \%$ of adult men.

These findings suggest that total $\mathrm{Fe}$ available in the typical diets of West African 
countries does not meet the physiological requirements of large proportions of the population. Absorption studies would be particularly useful for correlating the prevalance of Fe deficiency in a population with certain types of diets and as a guide in fortification programs.

This work was supported by a 'Contrat de Recherche Externe' de l'INSERM (Institut National de la Santé et de la Recherche Médicale), no. 867003.

\section{REFERENCES}

Association of Analytical Chemists (1975). Official Methods of Analysis 12th ed. Washington, DC: AOAC.

Conrad, A., Schuman, S., Kreutz, F. H. \& Sieber, A. (1978). Elaboration of method for the quantitative determination of proteins by laser nephelometry in the clinical routine laboratory. Journal of Clinical Chemistry and Clinical Biochemistry 16, 299-305.

Cook, J. D., Alvarado, J., Crutnisky, A., Jamba, M., Labardini, J., Layrisse, M., Linares, J., Loria, A., Raspes, V., Restrepo A., Reynafarje, C., Sanchez-Medal, L., Velez, H. \& Viteri, F. (1971). Nutritional deficiency and anemia in Latin America: a collaborative study. Blood 38, 591-603.

Cook, J. D., Layrisse, M. \& Finch, C. A. (1969). The measurement of iron absorption. Blood 33, 421-429.

Cook, J. D. Layrisse, M., Martinez-Torres, C., Walker, R., Monsen, E. \& Finch, C. A. (1972). Food iron absorption measured by an extrinsic tag. Journal of Clinical Investigation 51, 805-815.

Eakins, J. D. \& Brown, D. A. (1966). An improved method for the simultaneous determination of iron-55 and iron-59 in blood liquid scintillation counting. International Journal of Applied Radioactive Isotopes 17, 391-397.

Giovanello, T. J., Di Benedetto, G., Palmer, D. W. \& Peters, T. (1968). Fully and semi-automated methods for the determination of serum iron and total-iron-binding capacity. Journal of Laboratory and Clinical Medicine $71,874-880$.

Guiro, A. \& Hercberg, S. (1988). Iron exchangeability from pearl millet and Senegalese pearl millet meals. Nutrition Reports International 38, 231-238.

Hallberg, L. (1980). Iron absorption. In Iron pp. 116-133 [J. D. Cook, editor]. London: Churchill Livingstone.

Hallberg, L. \& Bjorn-Rasmussen, E. (1981). Measurement of iron absorption from meals contaminated with iron. American Journat of Clinical Nutrition 34, 2808-2815.

Hallberg, L., Bjorn-Rasmussen, E., Garby, L., Rossander, C., Pleemachinda, R. \& Tontawiroon, M. (1983). Iron absorption from some Asian meal containing contamination iron. American Journal of Clinical Nutrition 37, $272-277$.

Hallberg, L., Bjorn-Rasmussen, E., Howard, L. \& Rossander, L. (1979). Dietary haem iron absorption. A discussion of possible mechanisms for the absorption-promoting effect of meat and for the regulation of iron absorption. Scandinavian Journal of Gastroenterology 14, 769-779.

Hercberg, S., Chauliac, M., Galan, P., Devanlay, M., Zohoun, I., Agboton, Y., Soustre, Y., Bories, C., Auvert, B., Masse-Raimbault, A. M. \& Dupin, H. (1988). Prevalance of iron deficiency and iron-deficiency anemia in Benin. Public Health 102, 73-83.

Hercberg, S., Chauliac, M., Galan, P., Devanlay, M., Zohoun, I,. Agboton, Y., Soustre, Y., Bories, C., Christides, J. P., Potier de Courcy, G., Masse-Raimbault, A. M. \& Dupin, H. (1986). Relationship between anemia, iron and folacin deficiency, haemoglobinopathies and parasites infestation. Human Nutrition: Clinical Nutrition 40C, $371-379$.

Hercberg, S., Galan, P., Chauliac, M., Masse-Raimbault, A. M. Devanlay, M., Alihonou, E., Bileoma, S., Zohoun, I., Christides, J. P. \& Potier de Courcy G. $(1987 b)$, Nutritional anaemia in Beninese pregnant women: Consequence on haematological profile of newborn. British Journal of Nutrition 57, 185-193.

Hercberg, S., Galan, P. \& Dupin, H. (1987a). Iron deficiency in Africa. World Review of Nutrition and Dieletic.s 54, 201-236.

Magnusson, B., Bjorn-Rasmussen, E., Hallberg, L. \& Rossander, L. (1981). Iron absorption in relation to iron status. Model proposed to express results of foods iron absorption measurements. Scandinavian Journal of Haematology 27, 201-208.

Schricker, B. R. \& Miller, D. D. (1982). Measurement and content of non-haem and total iron in muscle. Journal of Food Science 47, 740-743.

Voller, A. \& De Savigny, D. (1981). Enzyme-linked immunosorbent assay (ELISA). In Techniques in Clinical Immunology, pp. 157-168 [R. A. Thomson, editor]. London: Blackwell Scientific Publications. 